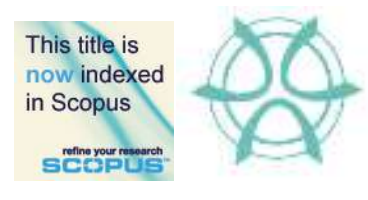

PLANNING MALAYSIA:

Journal of the Malaysian Institute of Planners

VOLUME 18 ISSUE 4 (2020), Page 299 - 311

\title{
PROFILING OF ISLAMIC CALLIGRAPHY SCRIPTS USED FOR ARCHITECTURAL DECORATION OF MASJID IN PENINSULAR MALAYSIA
}

\author{
Zumahiran Kamarudin $^{1}$, Ziad Baydoun ${ }^{2}$, Nik Ahmed Mazlan Nik Mahidin ${ }^{3}$ \\ ${ }^{1,2}$ Kulliyyah of Architecture and Environmental Design \\ INTERNATIONAL ISLAMIC UNIVERSITI MALAYSIA \\ ${ }^{3}$ I-NAI Venture Holdings Sdn. Bhd.
}

\begin{abstract}
In Malaysia, the introduction of the Islamic calligraphy, especially after the spread of Islam in the 14th century has impacted on the further development of decorative art in the built environment. While Islamic calligraphy has witnessed significant developments in the past decades, it still lacks a profiling classification system of calligraphy scripts that give impact to the contemporary mosque. The objectives of the study are to analyse the visual qualities of the calligraphy scripts in the mosque components and its compositional categories and to determine the relationship between the calligraphy placement and the mosque architecture within the interior and exterior fabrics of the buildings. This research involved an analytical review of the Islamic calligraphy found in the 10 selected mosques in Selangor and Kuala Lumpur, Malaysia and their depiction in various components. Face-to-face interviews with the mosque authorities and local calligraphers on the types and styles of scripts used in the mosque components were conducted as a complementary measure to the analytical method. The analysis reveals the application of cursive and angular style of scripts, fabricated in specified shapes, sizes and dimensions of the mosque components. Selection and depiction of calligraphy, especially in Thuluth and Kufi scripts suggest their strong preference to the traditional major styles ranging from its composition to the determination of its positional layout regardless of differences in the mosque architecture style.
\end{abstract}

Keywords: Islamic calligraphy, mosque architecture, calligraphy scripts

\footnotetext{
${ }^{1}$ Lecturer at International Islamic University Malaysia. Email: zumahiran@iium.edu.my
} 
Zumahiran Kamarudin, Ziad Baydoun, Nik Ahmed Mazlan Nik Mahidin

Profiling of Islamic Calligraphy Scripts Used for Architectural Decoration of Masjid in Peninsular Malaysia

\section{INTRODUCTION}

Islamic calligraphy is prevalent in Islamic art and architecture and has become one of the central features in the Muslim religious buildings, especially in the masjid. This gives escalation and appreciation to the idea that forms of calligraphic writing script can be applied as aesthetic units in its own right for specific places. The versatility and qualities of the calligraphy afford further development in the ornamentation of mosque architecture reflecting innovativeness in design yet in line with the Islamic world views. Many mosques, in general, are adorned with the calligraphy scripts that has become an essential decorative element since it adds the Islamic values to the buildings apart from giving aesthetic pleasing. The beautifully-written sacred text of Islamic calligraphy ties primarily with Divine words of God (Hamidon \& Ishak, 2015). However, the origin of the decorative scripts and how it was selected and developed for the specific mosque is not widely known. Many contemporary mosques are adorned with the calligraphic scripts, yet there is very little known about the decorative calligraphic scripts that have become part and parcel of its architectural significance.

Furthermore, little research was conducted on the categorisation of calligraphic scripts and is still not reaching to the fine and modest way of classifying its usage as architectural decoration due to its complexity in styles and scriptwriting. Development of different kinds of Islamic calligraphic scripts throughout the historical periods leads to the difficulty in recognising the scripts. Traditional calligraphers used different methods in writing the scripts, and it depends on their origin and personal background. Also, there are many cases of engaging various scripts to enhance works of art whilst supporting a range of functions of its usage and application. Jainal (2005) states that calligraphers need to maintain their artistic skill and to practise writing regularly. This certainly demands a high level of skill and specialised workmanship to achieve coherence, avoiding complication, muddles and mistakes.

In masjid, the same phenomena can be observed and therefore, there is a need to identify and categorise the application and placements of the scripts through a systematic approach. Developing a profile of Islamic calligraphy scripts used for mosque beautification will assist in identifying categories of calligraphy scripts, which are significant for its further sustainable development. Therefore, the objectives of this research are: to analyse the visual qualities of the calligraphy scripts in the mosque components and its compositional categories and to determine the relationship between the calligraphy placement and the mosque architecture within the interior and exterior fabrics of the buildings.

\section{ISLAMIC CALLIGRAPHY AND ITS MEANINGS}

Calligraphy is a type of visual art, and the term was derived from Greek, kallos "good" and graphẽ "writing". The term is generally defined in Webster's 
dictionary as beautiful or elegant handwriting. According to (Campedelli, 2010), all works of calligraphy shared a common feature of the text, which is in good form of letters. As such, calligraphy can be described as an art of writing in using letters stylistically and exquisitely. Meanwhile, Khatibi and Muhammed (1994) posit that the Islamic calligraphy is a beautifully-written sacred text since it deals primarily with Divine words of God. The calligraphy which is based on Arabic script is interpreted according to the cultural and aesthetic systems of a particular Muslim community (Abd Rahman, 2007) which shares a common Islamic cultural heritage hence it is also known as Arabic calligraphy. Arabic is a language of Islam due to its status as a vehicle of revelation (Mohamed, 1979). Hence, both terms Islamic calligraphy and Arabic calligraphy are considerably related and applicable. As such, the Islamic calligraphy is an art of beautiful writing that is an abstract expression of Islam.

\section{Islamic Calligraphy and Styles of Scripts}

Calligraphy is considered the quintessential art form of the Islamic world with Arabic letters decorating objects ranging from bowls to buildings (Othman, Aird, $\&$ Buys, 2015). The art of writing has gained wide popularity throughout the Muslim world due to its profound characteristics. The calligraphy is often considered as the most profound Islamic art because it is inspired by the verses in Qur'an (Sulaiman, 1997; Hamzah., 2012). Furthermore, among pious Muslims, the act of writing calligraphy is considered as a form of spiritual purification (Khatibi and Mohammed, 1994). As calligraphy is the artistic exercise of handwriting, it is created upon the alphabet in the lands that sharing a common Islamic cultural tradition (Hamidon \& Ishak, 2015). Calligraphy has been an essential medium in the arts of the Muslim cultures for many centuries because the use of figurative elements is prohibited by Islamic teaching (Mohamed, 1979; Othman, 1995). Likewise, calligraphers were among the most highly regarded artists in Islamic societies, and today, this remains the case in many places (Pedersen, 2014).

The traditional classification of Arabic writing falls into two major styles (Yasin, 1978): (1) Angular script, and (2) cursive script. The first category of calligraphic styles is generally called the Kufi or Kufic, the hardstyle. The second category is the soft style which includes Naskhi, Thuluth, Nastaliq, and many others. The Arabic alphabet developed rapidly after the rise of Islam in the 7th century into a beautiful form of art. On the roles of Islamic calligraphy, Sulaiman (1997: 23) posits that "the physical, visual and psychological ambience that the script pervades is spiritually enriching the souls of those who come into contact with it. In their capacities as a talisman, not only render them protection against evil forces or elements but more importantly, their regular contact with the divine text implicitly constitute a form of dhikr (invocation), which beyond 
Zumahiran Kamarudin, Ziad Baydoun, Nik Ahmed Mazlan Nik Mahidin

Profiling of Islamic Calligraphy Scripts Used for Architectural Decoration of Masjid in Peninsular Malaysia

doubt, is spiritually enriching". Meanwhile, Dzul Haimi (2007) states that the acts of making art or performing duties by Muslims are considered as a form of manifestation of their faith to Allah. As Kornfeld (2018) explains the Dome of the Rock and early Islamic coinage use Qu'ranic quotations to declare Islam as the monotheistic faith. This study proves that the manifestation of traditional ornamentation does play an important role not only in disseminating the symbolic meaning but also representing the history, beliefs and background of the local Malays.

\section{RESEARCH METHODS}

This study involved a profound review of related researches and literature and identifying of issues related to the art of Islamic calligraphy concerning its sociocultural dimension, sustainability issues, especially about its placement as architectural decoration in the masjid. The literature reviews also covered the calligraphy styles and the importance of the calligraphy scripts for the decoration. At this phase of research, a set of research parameters have been formulated to conceptualise the study in the context of the field of knowledge, i.e. Islamic calligraphy, architectural decoration, mosque architecture and Islamic art. The secondary data obtained from local authorities served as initial research techniques which provide shreds of evidence from which the authors were able to construct meaningful inferences and interpretation about the research inquiry concerning the first research objective.

\section{Qualitative Methods of Data Collection}

A qualitative approach of data collection was conducted through site visits and direct observation to the 10 selected mosques in Selangor and Kuala Lumpur. The researchers visited a total of 4 mosques with modernistic architectural styles; 1) Masjid Tun Abdul Aziz in Petaling Jaya, 2) Masjid Puncak Alam in Bandar Puncak Alam, 3) Raja Haji Fisabilillah Mosque in Cyberjaya, and, 4) Masjid Negara in Kuala Lumpur. The research also included 3 mosques with the style of post-modern revivalism; 1) Masjid Wilayah, Kuala Lumpur, 2) Masjid Sultan Salahuddin Abdul Aziz (Blue mosque) in Shah Alam and 3) Masjid Al Mukarramah in Petaling, Selangor. Also, the researchers selected the 3 mosques with Modern Vernacular design for the site visit; 1) Masjid Jamek Kampung Baru in Kampung Baru, Kuala Lumpur, 2) Masjid Sultan Abdul Samad in Sepang, and 3) Masjid Al-Hidayah, Taman Melawati, Kuala Lumpur. During this phase of research, visual inspections and photography documentation are important research techniques since this research seeks to analyse and categorise the styles of calligraphy scripts used for the mosque's decoration and its placement within the interior and exterior fabrics of the mosque. The researchers developed selection criteria to determine the eligible mosques for the research, and this includes the status, location, architectural style and availability of the calligraphy 
scripts. The researchers had researched with the help of using appropriate research instruments, including a checklist of calligraphic attributes, digital camera and recorder and measuring tools. The research also involved Face-toface and semi-structured interviews with local calligraphers, municipal authorities, and mosque authorities in obtaining an expert opinion on the development and application concept of Islamic calligraphy scripts in the mosque and policy use for the application of the various scripts. Related authorities, including Jabatan Kemajuan Islam Malaysia, and Jabatan Agama Islam Selangor also involved. The personal interviews with the 3 selected calligraphers from Selangor aimed to obtain information about the art of Islamic calligraphy including the styles of script, roles of the scripts, its application and identification of its traditional and socio-cultural values. The calligraphers also provided information on their perceptions of the calligraphy scripts in the mosque and its application. The researchers used content analysis of the textual and pictorial data obtained from the face-to-face interviews, site visits and field observation. The visual analysis were the primary instruments for the content analysis, and the thematic analysis was in the forms of descriptive and interpretive analysis on the interview transcription. The results and findings from the site visit, visual analysis and interview were useful research components as it helped in developing a profile of Islamic calligraphy scripts used for ornamentation of Malaysian masjid.

\section{ANALYSIS, RESULTS AND FINDINGS Visual Qualities of the Calligraphy Inscription}

The analysis shows that Thuluth script is the most recurrent calligraphy style found in many components of the mosques as highlighted in Table 1. This type of script is extensively prevalent at the Qiblah wall and the base of the domes. The result suggests Thuluth script has gained popularity as an ornamental inscription for the mosque decoration as apparent in the selected mosques of Selangor and Kuala Lumpur. According to Maryam (2018), Thuluth that has spectacular flexibility and the readable script remains the most significant of all the ornamental script. Kufi is a secondary type of script found in the mosques. The analysis also reveals that concentration of decorative calligraphy happens in few places of the mosques, especially in the prayer hall, which includes mihrab (praying niche) area, qiblah (direction of prayer) wall, domes, doorways, interior walls. Apart from these areas, many calligraphic inscriptions are found at the upper part of doorways and entrance archways. Qur'anic verses are dominant inscriptions found at mihrab, qiblah wall, domes, doorways, interior walls. Apart from the verses, various Islamic phrases and words adorn the places including Asmaul Husna (99 names of Allah), Basmallah phrase, companions' names, zikr (remembrance of God phrases) and dua (prayer of supplication quotes). The 
Zumahiran Kamarudin, Ziad Baydoun, Nik Ahmed Mazlan Nik Mahidin

Profiling of Islamic Calligraphy Scripts Used for Architectural Decoration of Masjid in Peninsular Malaysia

results show that Qiblah wall is the most ornate part of the mosques but in a moderate way.

Table 1: Visual qualities and compositional categories

\begin{tabular}{|c|c|c|c|c|c|}
\hline$\tilde{z} \stackrel{g}{\Xi}$ & $\begin{array}{l}\text { Placement/ } \\
\text { component }\end{array}$ & Position & $\begin{array}{l}\text { Calligraphic } \\
\text { Phrase/word }\end{array}$ & $\begin{array}{l}\text { Style of } \\
\text { script }\end{array}$ & $\begin{array}{l}\text { Compositional } \\
\text { category }\end{array}$ \\
\hline \multirow{6}{*}{ 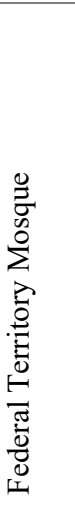 } & Mimbar & Upper part & Al-Baqarah:150 & Thuluth & Single image \\
\hline & Qiblah wall & Upper part & $\begin{array}{l}\text { Al-A'araf:206, Al- } \\
\text { Muzammil:20, Al- } \\
\text { Fatihah: 1-7, Al- } \\
\text { Insyirah:1-8 }\end{array}$ & $\begin{array}{l}\text { Thuluth } \\
\text { (cursive) }\end{array}$ & $\begin{array}{l}\text { Symmetrical } \\
\text { position }\end{array}$ \\
\hline & Main Dome & Base & Asmaul Husna & Thuluth & Single image \\
\hline & $\begin{array}{l}\text { Iwan/ } \\
\text { archway }\end{array}$ & $\begin{array}{l}\text { Arch } \\
\text { profile }\end{array}$ & At-Taubah:18-22 & Thuluth & $\begin{array}{l}\text { Single image, } \\
\text { Linear format }\end{array}$ \\
\hline & $\begin{array}{l}\text { Ablution } \\
\text { area/entrance }\end{array}$ & Upper part & Al-Kawthar:1-3 & Thuluth & $\begin{array}{l}\text { Single image, } \\
\text { linear horizontal }\end{array}$ \\
\hline & $\begin{array}{l}\text { Entrance } \\
\text { doorway }\end{array}$ & Upper part & $\begin{array}{l}\text { Ar-Rum:3, Ar-Ra'd: } \\
\text { 28, Al-Hajj:77 }\end{array}$ & Thuluth & Single image \\
\hline \multirow{5}{*}{ 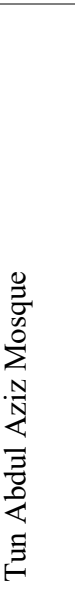 } & Mimbar & Upper part & $\begin{array}{l}\text { Annur: 56, Al Imran: } \\
\text { 133, Al Hasyr: } 18\end{array}$ & Thuluth & $\begin{array}{l}\text { Symmetrical } \\
\text { position }\end{array}$ \\
\hline & $\begin{array}{l}\text { Qiblah wall/ } \\
\text { emblem }\end{array}$ & Upper part & $\begin{array}{l}\text { Kalimah Allah and } \\
\text { Muhammad }\end{array}$ & Thuluth & $\begin{array}{l}\text { Symmetrical } \\
\text { position/pairing }\end{array}$ \\
\hline & $\begin{array}{l}\text { Main Dome/ } \\
\text { base and inner } \\
\text { space }\end{array}$ & Upper part & $\begin{array}{l}\text { Qur'anic verses } \\
\text { (Annur: ) } \\
99 \text { names of Allah }\end{array}$ & $\begin{array}{l}\text { Thuluth } \\
\text { Thuluth }\end{array}$ & Single image \\
\hline & $\begin{array}{l}\text { Prayer } \\
\text { hall/Wall } \\
\text { Facades }\end{array}$ & Upper part & $\begin{array}{l}\text { Qur'anic verses } \\
\text { (Al Kahfi:107-109, Al } \\
\text { Kahfi: 10, Al Anfal: } \\
\text { 1-2, Al Anfal: 3-4) }\end{array}$ & $\begin{array}{l}\text { Thuluth } \\
\text { Nastaliq } \\
\text { Diwani } \\
\text { Kufi } \\
\text { (angular) }\end{array}$ & Single image \\
\hline & $\begin{array}{l}\text { Roof/ } \\
\text { Signage }\end{array}$ & Top part & Name of the Mosque & $\begin{array}{l}\text { Kufi } \\
\text { (angular) }\end{array}$ & Single image \\
\hline \multirow{3}{*}{ 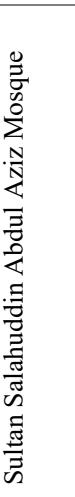 } & $\begin{array}{l}\text { Prayer hall } \\
\text { Wall }\end{array}$ & Upper part & $\begin{array}{l}\text { Salawat -salutation } \\
\text { phrase }\end{array}$ & $\begin{array}{l}\text { Thuluth } \\
\text { jali }\end{array}$ & Single image \\
\hline & Qiblah wall & Upper part & $\begin{array}{l}\text { Al-Fatihah: 1-7 } \\
\text { Al-Nas, Al-Falaq } \\
\text { Al-Ikhlas }\end{array}$ & $\begin{array}{l}\text { Thuluth, } \\
\text { Naskh, } \\
\text { Diwani, } \\
\text { Riq'ah, } \\
\text { Nastaliq }\end{array}$ & $\begin{array}{l}\text { Symmetrical } \\
\text { position }\end{array}$ \\
\hline & Main Dome & $\begin{array}{l}\text { Base- } \\
\text { exterior } \\
\text { Interior } \\
\text { base } \\
\text { Inner side }\end{array}$ & $\begin{array}{l}\text { Al-Taubah: 18-19 } \\
\text { Ya Sin: 1-11 } \\
\text { Al-Nisa:103 }\end{array}$ & $\begin{array}{l}\text { Thuluth } \\
\text { Thuluth } \\
\text { Thuluth }\end{array}$ & $\begin{array}{l}\text { Linear format } \\
\text { Linear format } \\
\text { Roundel } \\
\text { inscription }\end{array}$ \\
\hline
\end{tabular}


PLANNING MALAYSIA

Journal of the Malaysia Institute of Planners (2020)

\begin{tabular}{|c|c|c|c|c|c|}
\hline \multirow{4}{*}{ 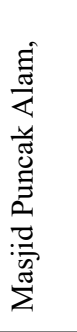 } & Qiblah wall & $\begin{array}{l}\text { Border of } \\
\text { mihrab }\end{array}$ & $\begin{array}{l}\text { Basmallah and } \\
\text { Qur'anic verse }\end{array}$ & Thuluth & Single image, \\
\hline & $\begin{array}{l}\text { Main door of } \\
\text { the prayer hall }\end{array}$ & Upper part & Dua & Thuluth & linear format \\
\hline & Main Dome & Base & Zikir phrases & Thuluth & Repeat, rotated \\
\hline & Mihrab wall & Upper part & Al-Shahadah phrase & $\begin{array}{l}\text { Square } \\
\text { Kufi }\end{array}$ & Single image \\
\hline \multirow{5}{*}{ 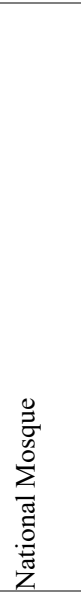 } & Qibla wall & Upper part & $\begin{array}{l}\text { Qur'anic verses } \\
\text { Al-Jinn, 72:18 } \\
\text { Al-Baqarah, 2:148 } \\
\text { Al-Taubah, 9:105 } \\
\text { Al-Hijr, 15:9 }\end{array}$ & $\begin{array}{l}\text { Thuluth } \\
\text { (cursive) }\end{array}$ & $\begin{array}{l}\text { Single image, } \\
\text { linear format }\end{array}$ \\
\hline & Mihrab & Upper part & Qur'anic verses & Thuluth & $\begin{array}{l}\text { Single image } \\
\text { linear }\end{array}$ \\
\hline & Main dome & $\begin{array}{l}\text { Inside the } \\
\text { dome }\end{array}$ & Basmallah and dua & Thuluth & $\begin{array}{l}\text { Single image } \\
\text { rotary }\end{array}$ \\
\hline & $\begin{array}{l}\text { Prayer } \\
\text { hall/Wall } \\
\text { Facades }\end{array}$ & Upper part & Qur'anic verses & Thuluth & $\begin{array}{l}\text { Single image, } \\
\text { linear format, } \\
\text { horizontal }\end{array}$ \\
\hline & wall Signage & Upper part & Name of the Mosque & $\begin{array}{l}\text { Kufi } \\
\text { (angular) }\end{array}$ & Single image \\
\hline \multirow{4}{*}{ 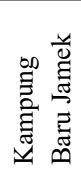 } & Front door & Upper part & Al-Hijr: 46 & Thuluth & Single image \\
\hline & Main Dome & Base & At-Taubah: 18 & Thuluth & Linear format \\
\hline & Mihrab & Upper part & Al-Jinn: 18 & Thuluth & Single image \\
\hline & Main Gate & Top part & At-Taubah: 18 & Thuluth & Single image \\
\hline \multirow{5}{*}{ 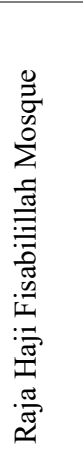 } & Qiblah wall & $\begin{array}{l}\text { Frame } \\
\text { border }\end{array}$ & $\begin{array}{l}\text { An-Nas, Al-Falaq, Al- } \\
\text { Ikhlas, } \\
\text { Inscription Allah and } \\
\text { Muhammad }\end{array}$ & Thuluth & $\begin{array}{l}\text { Single image } \\
\text { and double } \\
\text { format }\end{array}$ \\
\hline & Main & Upper part & Basmallah & Square & Single image \\
\hline & Entrance & Upper part & $\begin{array}{l}\text { Inscription Allah and } \\
\text { Muhammad }\end{array}$ & $\begin{array}{l}\text { Kufi } \\
\text { Square } \\
\text { Kufi }\end{array}$ & Double format \\
\hline & Dome, interior & Base & Al-Zalzalah & Thuluth & Rotary linear \\
\hline & Roof & Top part & lailahaillalah & $\begin{array}{l}\text { Knotted } \\
\text { Kufi }\end{array}$ & Repeated \\
\hline \multirow{2}{*}{ 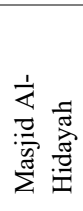 } & $\begin{array}{l}\text { Qiblah wall } \\
\text { (Mihrab) }\end{array}$ & Upper part & $\begin{array}{l}\text { Al-Baqarah, 2:149 } \\
\text { Allah \&Muhammad }\end{array}$ & $\begin{array}{l}\text { Thuluth } \\
\text { Square } \\
\text { Kufi }\end{array}$ & $\begin{array}{l}\text { Single image } \\
\text { Double format }\end{array}$ \\
\hline & $\begin{array}{l}\text { Entrance } \\
\text { Signage }\end{array}$ & $\begin{array}{l}\text { On the } \\
\text { ground }\end{array}$ & Name of the Mosque & $\begin{array}{l}\text { Thuluth } \\
\text { (cursive) }\end{array}$ & Single image \\
\hline
\end{tabular}


Zumahiran Kamarudin, Ziad Baydoun, Nik Ahmed Mazlan Nik Mahidin

Profiling of Islamic Calligraphy Scripts Used for Architectural Decoration of Masjid in Peninsular Malaysia

\begin{tabular}{|c|c|c|c|c|c|}
\hline \multirow{2}{*}{ 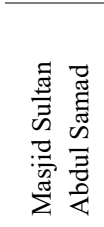 } & Qibla wall & $\begin{array}{l}\text { Upper part } \\
\text { Border } \\
\text { Border }\end{array}$ & $\begin{array}{l}\text { Al-Baqarah, } 149 \\
\text { Allah and Muhammad } \\
\text { Ayat al-Kursi }\end{array}$ & $\begin{array}{l}\text { Thuluth } \\
\text { Square } \\
\text { Kufi } \\
\text { Kufi }\end{array}$ & $\begin{array}{l}\text { Single image, } \\
\text { repeated and } \\
\text { Linear } \\
\text { Linear }\end{array}$ \\
\hline & Main Dome & Base & Qur'anic verses & Thuluth & linear format, \\
\hline \multirow{3}{*}{ 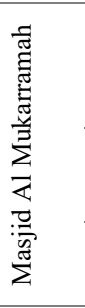 } & Qibla wall & Upper part & $\begin{array}{l}\text { Al-Baqarah, 2:255 } \\
\text { Al imran, :102 } \\
\text { Al Haj:77 }\end{array}$ & $\begin{array}{l}\text { Thuluth } \\
\text { (cursive) }\end{array}$ & $\begin{array}{l}\text { Single image, } \\
\text { linear format, } \\
\text { Rotary }\end{array}$ \\
\hline & Mihrab & $\begin{array}{l}\text { Top } \\
\text { archway }\end{array}$ & Al-Baqarah, 2:144 & Thuluth & $\begin{array}{l}\text { Single image, } \\
\text { linear format, }\end{array}$ \\
\hline & Main dome & Base & Asmaul Husna & Thuluth & $\begin{array}{l}\text { Single image, } \\
\text { linear format, }\end{array}$ \\
\hline
\end{tabular}

\section{Compositional Categories of the Calligraphic Decoration}

The calligraphy found in the mosque performs both functional and aesthetic purposes, and without the calligraphic decoration, the mosque architecture would not be complete. The Islamic inscriptions found in the mosques either derived from Qur'anic verses or other phrases are not only significant for decoration purposes. They also play their roles to spread the message of Islam either to Muslims or non-Muslim visitors. These inscriptions remind the visitors to the greatness of Allah and also remind them of their responsibilities as Muslims. In

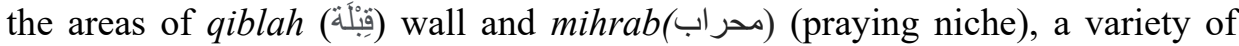
calligraphy styles adorn the upper part of the wall. They are often found interwoven as apparent in the qiblah wall of Federal Territory Mosque, Kuala Lumpur (Figure 1). Qiblah wall in a mosque faces Mekah, in which the mihrab is located at the centre point to the direction of Mekah, or indicates the Kaaba (الكعبة). In Islam, the sacred direction is towards the sacred Kaaba in Mekah. Thus, in a mosque, the qiblah wall is sacred for the praying hall, known as sacred space (Norhayati et al., 2014). Thus, the abundance of calligraphic inscriptions found on this wall is due to its significant status. The vivid articulation of calligraphic inscriptions along the wall is an indicative gesture of how important the qiblah wall is as evident in the visited mosques. An interesting feature of the qiblah wall is that it can be directly seen from a distance because all of the mosques keep a single space layout. Nevertheless, because of the common function of the mosque as a place of congregational prayer, the qiblah wall becomes one of the most common architectural features, which appear in all visited mosques. 

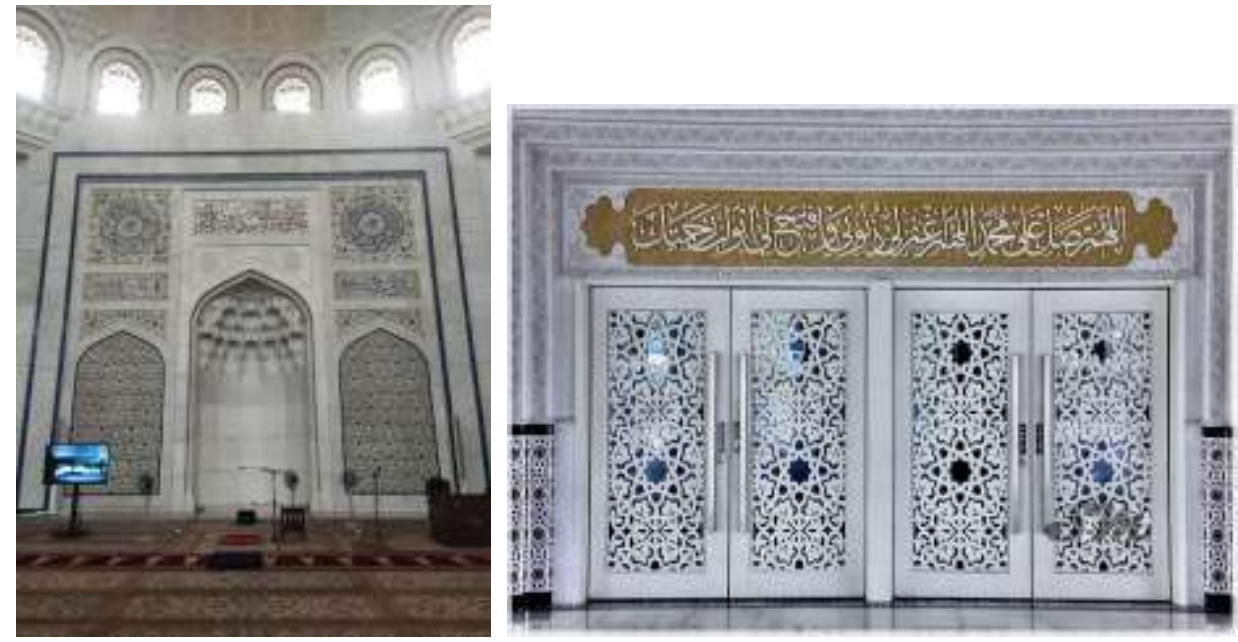

Figure 1: Qiblah walls of Federal Territory Mosque and a doorway at Puncak Alam Mosque with Thuluth inscriptions

An entrance doorway at Puncak Alam Mosque displays a prayer quote or dua written in Thuluth script. It shows easy read phrase using simple calligraphy-like thuluth script. The prayer quote means "O Allah, your blesses and prayers to the prophet Muhammad, O Allah forgive me and open to me the doors of your mercy." In Islam, $d u a$ is the very essence of worship, and Muslims can make dua at any time. The placement of the prayer quoted at the entrance of the prayer hall is significant as it can remind the worshippers to recite the $d u a$ while entering the place. A mosque should be a place that encourages them to invoke Him and increases their supplications in prostrations.

The analysis of the calligraphic inscriptions suggests that there are two main categories of compositional principles; 1 ) symmetrical or double image, and 2) standalone or single image. As shown in Table 1, the calligraphy found within the prayer hall has principal variants of phrases including Qur'anic verses, prayer quotes, the religious phrase in praise of Allah, and 99 names of Allah. Depiction of selected verses from Al Qur'an appears pervasively in most of Qiblah wall and mihrab either in a single position or double position. The result implies that the single type of composition is the most popular one, probably since the calligraphic script is complex in character, which should be handled prudently. Sense of sacredness in the calligraphic phrases is the prime thing. This is why the selection of calligraphy inscriptions reveal a deep preference for a religious text as a principal element. Placement of a single and double composition or symmetrical format of calligraphy inscriptions are prevalent at the qiblah wall, mihrab and main dome at the prayer hall. The dome is one of the most dominant 
Zumahiran Kamarudin, Ziad Baydoun, Nik Ahmed Mazlan Nik Mahidin

Profiling of Islamic Calligraphy Scripts Used for Architectural Decoration of Masjid in Peninsular Malaysia

features of the mosque as it seems to cover almost the entire area of the prayer hall; hence the placement of religious phrases in a single format is pertinent as apparent around the dome of Puncak Alam Mosque as shown in Figure 2. The text of Surah Al-Mukminun, verses 1-12 adorns the base of this dome in Thuluth script. It also appears that the mosques embrace the double image of calligraphy inscriptions that dominates the qiblah wall and mihrab as found in Masjid Tun Abdul Aziz, Petaling Jaya.
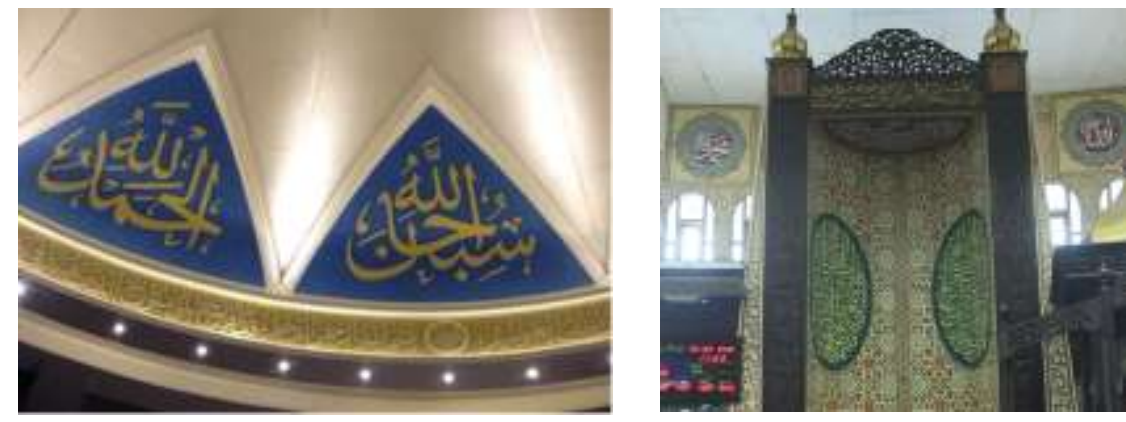

Figure 2: Single and double image of verses at the dome and mihrab, respectively

\section{The Relationship Between the Calligraphy Placement and the Mosque Architecture}

Islamic calligraphy is part and parcel of the language of mosque architecture. "It is a compelling fact that beautifying and decorating mosques, with sharply varying degrees and styles yet with the identical message and philosophy, is evident virtually everywhere from the moment the idea of beautifying mosques had been instituted till today" (Spahic, 2016; p16). This study had analysed the Islamic calligraphy found in the different mosques with different architectural styles. A few prominent mosques with the modernistic architectural styles like Raja Haji Fisabilillah Mosque in Cyberjaya and National mosque of Malaysia in Kuala Lumpur have a good collection of Arabic calligraphy at their praying halls. "National mosque is by far the best example of a building imbued with the technological and spiritual qualities of an architecture with a truly Malaysian identity classification of mosque styles" (Mohamad Tajudin, 2007; p30). Regardless of the differences in the forms and architectural style, the placement of the decorative calligraphy is in control and moderate manner because Islam prohibits extravagant mosque decoration and space beautification. The mosques, in its many forms, is the archetypal of Islamic religious building because of its sharing spiritual qualities. Similarly, regardless of the many local forms and styles of mosque architecture, the placement of calligraphy scripts as mosque decoration remain consistent. Raja Haji Fisabilillah Mosque and Tun Abdul Aziz mosque (Figure 3) portray the subtle use of calligraphy inscription although in its 
modernistic architectural style. The traditional Kufi scripts blend harmoniously with the contemporary-styled architecture of the mosques in an appropriate manner.
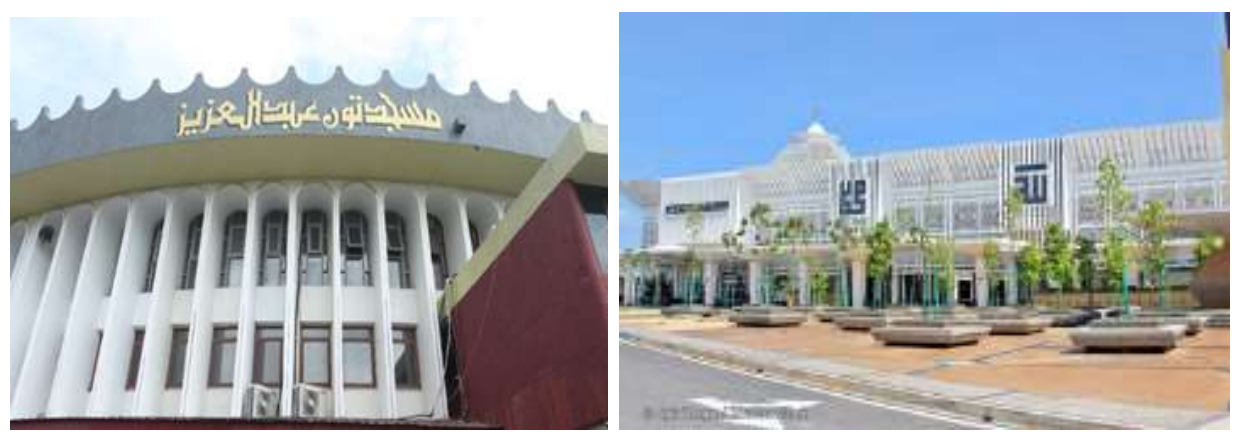

Figure 3: Signage position with different styles of Kufic script

Since masjid means place of prostration, the placements of decoration components at the interior and exterior of the mosques follow its meaning. This is in consonant with Spahic (2016), which emphasises the mosque decoration in the Muslim world should reflect the fundamental principles: 1) appropriateness and 2) purposefulness- serve for the spiritual goods. Even though the architecture of the mosque is shaped most strongly by the regional traditions of the place where it was built, the placement of decoration follows these fundamental principles. Likewise, Utaberta et al., (2012) in their study found that the manifestation of traditional ornamentation does play an important role not only in disseminating the symbolic meaning but also representing the history, beliefs and background of the local Malays.

In short, the selection of calligraphy inscriptions, the styles of scripts and their placements have no big difference between the mosques since they have the same objectives, that is to achieve the principles of appropriate and purposeful mosque decoration and space beautification. The findings show that the selection of calligraphy styles for each mosque remain consistent, but the varieties reflect on the use of religious phrases. Among the preferred ones are the inscriptions of Quranic verses, the prayer of supplication quotes, and 99 names of Allah. The finding of this research suggests a preliminary framework that regulates mosque decoration with Islamic calligraphy emphasising the decoration of the praying

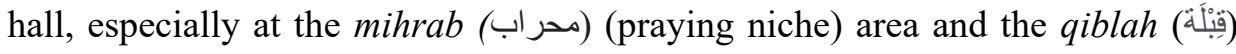
wall as observed in most of the mosques. 
Zumahiran Kamarudin, Ziad Baydoun, Nik Ahmed Mazlan Nik Mahidin

Profiling of Islamic Calligraphy Scripts Used for Architectural Decoration of Masjid in Peninsular Malaysia

\section{CONCLUSION}

The finding suggests that the Arabic calligraphy-inspired decoration found in the selected mosques were principally concentrated in certain areas, which includes the qiblah wall, mihrab, iwan and main entrance, doorways, walls of a prayer hall, domes, and front signage. The results suggest Thuluth script has gained popularity as an ornamental inscription for the mosque decoration as apparent in the selected mosques of Selangor and Kuala Lumpur, however it is not restricted to the cursive styles of calligraphy script. The angular script, namely Kufi, is prevalent in several mosques but not as extensive as the cursive script. Findings of this research offer a preliminary framework of the profiling that regulate mosque decoration with Islamic calligraphy. The profiling would assist in identifying categories of calligraphy scripts in mosque decoration. Also, this will aid comprehension among users, designers and authorities, and contributing to the sustainability of calligraphy as Islamic heritage. The versatility and qualities of the calligraphy afford further development in the embellishment of mosque architecture reflecting innovativeness in design yet in line with the local guidelines, regardless of the differences in architectural style. The presence of Islamic calligraphy in the religious spaces would affect the physical and spiritual wellbeing of the users as well as the places.

\section{ACKNOWLEDGEMENT}

The authors would like to express their gratitude to the authorities of Jabatan Kemajuan Islam Malaysia, and Jabatan Agama Islam Selangor for approving the use of the documents for reference purposes. Appreciations are also due to the calligraphers and mosque authorities, who provided some valuable and insightful information for this study.

\section{REFERENCES}

Campedelli, M. (2010). Applied calligraphy and graphic design. Barcelona: LINKS.

Dzul Haimi Md. Zain. (2007). Ragam hias al-Qur'an di alam Melayu. Kuala Lumpur: Utusan Publications \& Distributors Sdn Bhd.

Hamidon, N. A., \& Ishak, S. M. M. (2015). The New Categorizations of Style in Contemporary Islamic Calligraphy Paintings in Malaysia. International Journal of Social Science and Humanity, 5(4), 403.

Hamzah, A. R. (2012). Islamic Inscription in Mosques Forms and Meanings. Kuala Lumpur: University Teknologi Malaysia.

Jainal Sakiban (2005). Seni khat keindahan dalam kepelbagaian, 'sejarah, tokoh dan karya'. Selangor: Synergymate Sdn. Bhd.

Khatibi, Abdelkebir and Mohammed Sijelmassi (1994). The splendor of Islamic

calligraphy. Paris: Thames and Hudson.

Kornfeld, A. M. (2018). Introduction to Islamic Art \& Architecture. 
PLANNING MALAYSIA

Journal of the Malaysia Institute of Planners (2020)

Mohamad Tajuddin Mohamad Rasdi, (2007). Mosque Architecture in Malaysia: Classification of Styles and Possible Influence. Jurnal Alam Bina, 9(3), 1-37.

Mohamed U. Zakariya, (1979). The calligraphy of Islam reflections on state of the art. Washington D.C.: Center for Contemporary Arab Studies.

Maryam, D. Ekhtiar. (2018). How to Read Islamic Calligraphy. The Metropolitan Museum of Art, New York.

Norhayati Kassim, Nora'shikin Abdullah, Zafrullah B. Mohd Taib, (2014). Decoration in Praying Hall of Mosque: A review of current literature. Procedia - Social and Behavioral Sciences. 153 (2014), 55 - 60.

Othman, Z., Aird, R., \& Buys, L. (2015). Privacy, modesty, hospitality, and the design of Muslim homes: A literature review. Frontiers of Architectural Research, 4(1), 1223.

Othman Mohd. Yatim (2009). Dekorasi Alam Melayu Dalam Konteks Ketauhidan. Proceedings of the International Conference on Art 2009. 5-6 August. Kuala Lumpur: University Malaya, 1-20.

Pedersen, J. (2014). The Arabic book (Vol. 688): Princeton University Press.

Spahic Omer (2016). Rationalizing the Permissibility of Mosque Decoration. Journal of Islamic architecture. 4(1), 14-26.

N. Utaberta, S. D. M. Sojak, M. Surat, A. I. Che-Ani and M.M. Tahir, (2012). Typological

Study of Traditional Mosque Ornamentation in Malaysia - Prospect of Traditional Ornament in Urban Mosque. International Journal of Civil, Environmental, Structural, Construction and Architectural Engineering 6 (7), 457-464.

Yasin Hamid Safadi (1978). Islamic Calligraphy. London: Thames and Hudson.

Received: $15^{\text {th }}$ May 2020. Accepted: $1^{\text {st }}$ Sept 2020 